\title{
KINSHIP AND MARRIAGE AMONG THE JAVANESE KYAI
}

\author{
Zamakhsyari Dhofier*
}

\section{Introduction}

In 1957 Professor Koentjaraningrat, the most senior Indonesian anthropologist in contemporary Indonesia, remarked that, at that time, no adequate description of the Javanese kinship system existed in the huge amount of literature that had been published on Javanese culture. Of the two studies on this system that he was then able to cite, one by Hurustiati Subandrio ${ }^{1}$ was restricted to a presentation of the kinship terminology, while the second, by Hildred Geertz ${ }^{2}$ although based on extensive fieldwork in a small town in East Java, could not cover variations in the kinship system of an ethnic group consisting of tens of millions of people in different areas and of different social levels. ${ }^{3}$

In his own work Koentjaraningrat described in particular the kinship system of the higher social levels of the Javanese in South Central Java. Although he viewed this work as only a starting point for further investigations, by himself and other scholars, of kinship behavior and its influence on the socialization process and personality formation of the Javanese individual, no subsequent works have, in fact, appeared in this field. Indonesianists who want to know about the Javanese kinship system have only these three sources on which to rely.

Acknowledging his ignorance of kinship systems among Javanese santri groups (those who seriously follow Islamic principles), Koentjaraningrat also suggested that an intensive study of them was needed. ${ }^{4}$ My present study on the kinship and marriage system among the Javanese kyai is intended as a preliminary contribution to the study of the santri groups. It is preliminary in the sense that the kyai are only part of the santri community and also that my data focuses on only some kyai families in Central Java and the two major kyai families in Jombang in East Java.

* This article is based on a paper read at the departmental seminar of the Department of Anthropology, Research School of Pacific Studies, The Australian National University, Canberra, Australia, on July 25, 1979. I am very much indebted to Professor James Fox of the A ustralian National University for reading and commenting on this article.

1. Hurustiati Subandrio, "Javanese Peasant Life: Villages in East Java" (Dissertation, University of London, 1951), pp. 52-73.

2. This Ph.D. thesis written in 1955 was then published as Hildred Geertz, The Javanese Family (New York: The Free Press of Glencoe, 1961).

3. Koentjaraningrat, A Preliminary Description of the Javanese Kinship System , Southeast Asia Studies Cultural Report Series (New Haven: Yale University, 1957), p. 1 .

4. Ibid., p. 12. 
2. The Place of Kyai and Their Families

in the Javanese Social Stratification

The status of an individual Javanese is determined by a set of factors--occupation, wealth, family, place of residence, religion, taste, and education--which are not highly intercorrelated. ${ }^{5}$ The result is that the pyramidal structure which characterizes the Javanese status stratification system is no simple one. Within it we can draw a vertical line to divide the Javanese into two discontinuous and differently structured communities, based on their degree of participation in Islam. ${ }^{6}$ There is also a stratification system within the faithful Muslim community, since particular groups of this community form definite social levels. Not all Javanese kyai can be placed in one particular social class although, in general, most of them could be included as members of the Javanese elite.

The lowest strata of the pyramidal structure stretch extremely widely while the highest strata are confined to a limited number of individuals. The great majority of the millions of Javanese living in Central and East Java belong to the lowest strata. Most of them are either landless or near-landless peasants in villages, or occupants of urban kampung (urban slums) who are employed as daily laborers or involved in handicraft manufacture, small trade, and hawking. The remaining Javanese villagers, although they own land (ranging between 0.5 ha to 4 or $5 \mathrm{ha}$ ) and enjoy more prestige than the landless/near-landless peasants, are still considered to belong to the lower levels of the Javanese stratification system. This is because the Javanese themselves do not recognize a "middle class" group. They distinguish two broad social levels, the wong cilik (little people), made up of the masses of peasants and lower-class people in towns and cities, and the wong gede or priyayi, a social level which comprises members of the civil service, administrative officials, and intellectuals. ${ }^{7}$ Theoretically, however, wealthy villagers, who own land of more than $3 \mathrm{ha}$, and who represent only a small percentage (probably less than 5 percent) of the rural population, and town dwellers, who are employed in the modern bureaucracy or in larger-scale trade, can be considered as a middle class.

Although most of the Javanese kyai live in rural areas, they can be included as part of the elite. ${ }^{8}$ This is because, as a group, influential ulama (religious leaders) have been an active, leading force in Indonesian politics. The kyai are

5. Clifford Geertz, The Social History of an Indonesian Town (Cambridge, Mass.: MIT Press, 1965), p. 127.

6. Students of Indonesian social, cultural, and political life have commonly acknowledged that a fundamental cleavage in the Indonesian community is between people who faithfully adhere to Islamic teachings and those who are only nominally Muslims. The 1971 census showed that together these groups represented 87 percent of the total population of Indonesia. Among faithful Muslims, there is a further cleavage between "traditionalists" who adhere to the four founders of Islamic jurisprudence (the Hanafites, the Malikites, the Syafi'ites, and the Hanbalites) and the "modernists" who take only the Qur'an and Hadiths as valid references. In Central and East Java the contrast between practicing faithful and lax Muslims is sharper than in other areas of Indonesia.

7. Koentjaraningrat, Preliminary Description, p. 2.

8. They have their external symbols, the kupyah (a round white cap indicating that they have performed the pilgrimage to Mecca) and the surban (special cloth of about one square meter which is worn in such a style as to cover the hair). 
usually wealthy landowners who, rather than engaging in farming, have teaching and preaching as their profession. To perform this job, they need to be sociopolitically aware, and they are regarded (and regard themselves) as having an authoritative presence on the local and the national scene; they are among the effective decision makers in the Javanese social system, not only in religious but also in political matters. They are what the Javanese regard as wong mulya (the honored) or, to use a more modern term, pemimpin (leaders). Their profession thus establishes kyai influence beyond village boundaries.

Ever since Islam first came to Java, the kyai have enjoyed a high social status. Under Dutch colonial rule, the Javanese sultans concerned themselves principally with the political aspects of their office, leaving Islam in the stricter sense to the dogmatists and traditionalists (the Javanese kyai), and thus fostering an unintended separation of religious and political authority. In the unofficial separation of powers which thus evolved, the kyai were recognized as having exclusive competence in the sphere of religious law. Islamic religious law regulates most social and personal relations, thus giving the Javanese kyai a pervasive role in the community. The mass of Javanese were dependent on the kyai for guidance and even for decisions on such matters as property, marriage, divorce, inheritance, and the like; and their influence in consequence was very strong. This, coupled with their aloofness from the state, gave them immense moral authority, and marked them off--in effect though not in theory--as a separate learned class. ${ }^{9}$

The Javanese kyai initially derive their influence primarily from their qualifications as Muslim scholars whose energies are directed to developing pesantren (traditional Islamic training centers for advanced studies): teaching santri (a term which is here applied to students of these pesantren) is their main daily activity. The more advanced a kyai's knowledge in the many branches of Islam, and the more proficient he is in developing his pesantren, the larger the number of santri attracted to study there. Big pesantren like Tebuireng in Jombang, Lirboyo in Kediri, Asembagus in Bondowoso, and Darussalam Blok Agung in Banyuwangi have more than 2,000 santri each. Their students come from various parts of Indonesia, and in the pesantren at Gontor in Madiun, for example, we even find santri who come from Singapore, Malaysia, Thailand, Brunei, and the Philippines. It is understood, then, that the influence of the kyai of these big pesantren can extend throughout the nation and beyond, and, consequently, the kyai are included as part of the national elite. During the first two decades of independent Indonesia, many of these kyai were appointed as government ministers, members of parliament, ambassadors, and as high government officials.

Being "centers of excellence" these big pesantren also train santri who become leaders of minor pesantren, which are culturally and intellectually dependent on major pesantren. There has been a process of interdependency between major and minor pesantren, in that major pesantren provide novice kyai to teach in the minor pesantren, which, in turn, provide santri with the elementary training necessary to continue their advanced studies in major pesantren. This relationship has also created an exclusive stratification system among the kyai: kyai of major pesantren form part of the national elite; kyai of secondary pesantren form part of the pro-

9. This was remarked on by the well-known court poet, Raden Ngabehi Yasadipura I, in the Serat Cabolek: "A man has more respect as an ulama than if he were a bupati [because] he is a minister of God. . . Even were there ten [ministers of a king], one ulama, . . . would be superior to them. In their heart, . . . the ulama are the best people of the world." S. Soebardi, The Book of Cabolèk (The Hague: Nijhoff, 1975), p. 42. 
vincial elites; while kyai of minor pesantren form part of local district elites. Since 1971, when the Suharto Government stopped recruiting members of the cabinet from various political groups, the Javanese kyai have not been represented in the executive body, but they are well represented in the legislative body, at both the national and regional levels.

Having many santri pupils increases not only the influence and leadership status of the kyai but also their wealth. Although individual yearly contributions paid by the santri only range between $\$ 10$ and $\$ 25$, this becomes a considerable amount when 2,000 santri are involved. This money is sometimes spent to increase land ownership (for example, that of Pesantren Ploso in Kediri).

To become a kyai, a novice must proceed through various stages. Initially, he must usually be a close relative of a kyai. After receiving an elementary Islamic education from local Muslim scholars (sometimes his own father) for about seven to ten years, he will continue for many years to pursue advanced Islamic studies in various pesantren. Besides being trained as a Muslim scholar, he will also assist in training and teaching junior santri and take part in leading the community . Careful personal attention and blessing from his own kyai are important in determining whether a novice will eventually be able to head his own pesantren. The kyai will pay special personal attention to a santri not only if he is intelligent and industrious in pesantren affairs, but also if he is a son or relative of another kyai; or, even more important, the kyai may be interested in taking the novice as his son-in-law. Thus, most kyai in Java are interrelated. In other words, running pesantren has become the interest of particular kin groups. These groups are Muslim scholars, imbued with a strong sense of duty to urge people to follow Islamic principles seriously and perform religious rituals intensively, and they have an interest in maintaining their pesantren leadership, preserving their position as part of the elite sector of the Javanese community, and in keeping their abundant wealth. These kyai have, then, developed a distinctive santri culture (a mixture of Javanese and Islamic culture), a variant of the Javanese culture of the abangan (nominal Muslim) groups. The Islamic focus of its kinship and marriage system forms part of this kyai culture.

\section{Ideals of Kinship among the Kyai}

The kyai regard the family unit as the foremost and fundamental institution of the Muslim community. A family is established by the coming together of a man and a woman, and their contact brings into existence a new generation. It then produces ties of kinship within the community, which gradually develop into a large society. Kyai regard the family as the institution through which a generation prepares the succeeding generation for the continuation of Islamic civilization and for the sincere and enthusiastic discharge of its social obligations. The institution recruits cadets not merely for the maintenance and development of santri culture, but also for its protection. Kyai earnestly desire that those who will replace them in the future be better than they are themselves. ${ }^{10}$ In this respect, the family is regarded as the fountainhead of the progress, prosperity, and strength of santri culture.

According to the Javanese kyai, the correct form of relationship between man and woman is marriage, that is, the one in which full social responsibilities are undertaken by them and which results in the emergence of a family. Sex is only

10. The kyai always expect that their children will become extraordinary persons who own ilmu laduni. (For a discussion of ilmu laduni, see below, pp. 52-53.) 
for reproduction within a regulated marriage. Hence, the kyai hold every form of extramatrimonial sexual relationship to be sinful, forbidden, and a crime under santri law. As the offense is regarded as a dosa besar (serious sin), they prescribe severe punishment for it. ${ }^{11}$ Activities which encourage or provide opportunities for such irresponsible actions must be avoided. Bans on the free mingling of men and women, restrictions on titillating music and pictures, and discouragement of the spread and propagation of obscenities and aberrations, are all measures intended to protect and strengthen the institution of the family. The kyai consider marriage as a good and virtuous act, indeed, as an act of worship. On the marriage certificate is always written the hadith (tradition of the Prophet) which maintains that "Marriage is my path, they who do not follow my path are not my followers." The kyai do not simply look upon adult celibacy with disfavor but call upon every young man to assume the social responsibilities of married life, just as his parents did in their time. They regard perpetual celibacy not as a virtue but as an aberration and departure from the true nature of man, and an act of revolt against the Divine scheme of things. Furthermore, though debarring certain specified relatives from marrying one another, they encourage matrimony between all other near and distant kin.

Within the family, they assign to the man the position of authority in order to maintain order and discipline in the household. They expect wives to obey and look after the comfort and well-being of their husbands, and children to behave in the same way towards their parents, especially with regard to the parents' order that the children follow an Islamic way of life. But if a woman is asked to obey her husband, the husband is also called upon to look after the welfare of his family and treat his wife with love and tenderness. Written in the marriage certificate is a verse of the Qur'an: ". . But consort with them in kindness, for if ye hate them it may happen that ye hate a thing wherein Allah hath placed much good" (Qur'an, IV, 19).

The kyai expect the marital bond to be strong, but their aim is to keep the bond intact only so long as it is founded on love or, at least, on the possibility of a lasting companionship. When this possibility dies out, the married couple is urged to separate temporarily, and under certain conditions, where married life has become a source of misery or nuisance, kyai may ask the Islamic courts of justice for authority to annul the marriage. The couple, however, must bear in mind that Islam considers divorce as a most hateful thing in the sight of God.

Although the kyai believe that men are given the right to be heads of families, they always expect husbands and wives to work together and have equal rights in managing the daily affairs of the family. They often quote a verse of the Qur'an (II , 187), "Your wife is your clothes and you are hers." Men and women were created by the same Divine breath, as it is written in surah al-Nisa', "O mankind! Be careful of your duty to your Lord who created you from a single soul and from it created its mate and from them twain hath spread abroad a multitude of men and women" (IV , 1).

In some respects, they give dignity of women precedence over that of men by quoting the popular hadith: "Paradise is under the feet of mothers." The reason for man being assigned the role of head of the family is because he is physically fitter to carry such a heavy responsibility. For these reasons, a Muslim woman

11. According to the kyai there are five kinds of dosa besar, which are called the mo limo (five $\mathrm{m}$ ). These are maling (theft), madon (playing with women in the sense of enjoyment of extramarital sexual intercourse), madat (smoking opium), main (gambling), and minum (alcoholism). 
must marry a Muslim man, while a Muslim man is strongly urged, but not required, to marry a Muslim woman.

The social sphere beyond that of the nuclear family is established by kinship. One's kin by virtue of common parents, or common brothers and sisters, or relations through in-laws, are expected to be mutually affectionate, cooperative, and helpful. Kyai frequently quote verses of the Qur'an enjoining good treatment of "dzawil qurba" (near relatives). In this, they are following the traditions of the Prophet whereby good treatment of one's relatives is emphasized and counted among the highest virtues. A person who cold-shoulders his relatives, or treats them in an indifferent manner, is looked on with disfavor.

\section{The Javanese Kyai's Family}

Kinship among the kyai plays a comparatively greater role in structuring their economic, political, and religious behavior than is the case among the average Javanese villagers. The kyai may not be considered an open class, because of their strong in-group feeling and their preference for class-endogamy. Although admission to membership is not ascribed by birth, the kyai have established a tradition that their descendants (especially sons and grandsons) and their immediate relatives (especially their sons-in-law) have a greater right than others to be recruited as new members.

The kyai as "the inheritors of the Prophets" 12 are particularly responsible for "protecting" their family and immediate relatives from losing God's blessing. "Protect yourself and your ahli from being thrown into Hell" (Qur'an, LXVI, 6). Ahli is a term frequently translated as sanak keluargamu (your relatives), and is not restricted to the members of the kyai's nuclear family.

Moreover, a successful pesantren leader also relies on the support of his family members. To organize his pesantren and to teach santri he needs badal (staff), who are mostly recruited from among his immediate relatives. In his early career as a kyai, before his own children are grown up, he gives special training to his younger brothers, nephews, or cousins, and sends them to some well-known pesantren, hoping that, upon their return, they can help him develop his own pesantren. Very frequently, he takes in his successful cousins as his sons-in-law. His immediate family also share the prestige and privileges enjoyed by the kyai.

Members of his nuclear family, of course, are entitled to special prestige. His wife obtains the title nyai. In East Java, his sons (and sometimes his grandsons) obtain the title gus, ${ }^{13}$ but his daughters have no special title. The kyai sees his gus as the potential successor to leadership of his pesantren. If he has no son, one of his sons-in-law will assume this role. He, therefore, always gives special training to his gus and possible sons-in-law to qualify them as successors.

By fostering the public image that gus inherit the spiritual attributes of their fathers, the kyai aim to legitimize their sons as their rightful successors. This is very important, because pesantren are simultaneously public institutions in the sense that they involve public interests, and the private property of the kyai. Their sons are in danger of being replaced by able "outsiders" (nonkin).

Thanks to their extraordinary lineage, most gus are believed to be able to acquire ilmu laduni (an ability to master various branches of Islamic knowledge

12. The original verse is "Al-ulama waratstul ambiya'."

13. This probably derives from the word si bagus, which means "the handsome one," or gusti, which means "the most respected." 
without studying). ${ }^{14}$ In other words, God has blessed gus with Islamic knowledge from the time they were born. They were born to become Muslim scholars, and they were born to lead pesantren. To other santri and the people in general, however, the kyai always say: "Learn hard, for nobody was born as an alim. Remember that men of knowledge cannot be equated with men without knowledge." 15

The title gus is very important because there is a strong tradition within the pesantren system that a gus who continues his studies in other pesantren receives special attention or tutorship from the kyai, so that his knowledge and leadership achievements surpass those of other santri. At Tebuireng, during the life of K. H. Hasyim Asy'ari, all gus were accommodated in a special ward. ${ }^{16}$

Most kyai also foster the public image that some kyai are extraordinary persons possessing the spiritual attributes of karomah (a man who is greatly loved by Allah) and so becoming sources of barakah (Allah's blessing) for their followers. ${ }^{17} \mathrm{Hav}^{-}$ ing karomah and being the source of barakah allow kyai to develop a charismatic leadership. Karomah, barakah and 'ilm (Islamic knowledge) are essential elements for pesantren leadership. Almost all well-known kyai who have been able to develop big pesantren are classified as kyai with extraordinary karomah and barakah. It seems to me, however, that these spiritual qualities are only attributed to kyai when they have already become well known. The kyai then foster them to preserve their popularity and attract santri. What makes kyai well known is primarily their great competence in various branches of Islamic knowledge together with their extraordinary organizational ability in developing their pesantren either by manipulating or establishing kinship ties with many well-known kyai, or by training highly capable novices. Hasyim Asy'ari, the greatest and the most well-known kyai throughout Indonesia during the first half of the twentieth century, offers an excellent example.

Hasyim Asy'ari was born of a distinguished family of kyai at a village near Jombang, East Java, in 1871. Asy'ari, his father, was the founder of Pesantren Keras, Jombang; Kyai Usman, his grandfather, was a well-known kyai and the

14. The kyai, however, believe that ilmu laduni can also be acquired by non-kyai children. The parents may expect God to give them children who own ilmu laduni if they perform the following practices and rituals: (a) during pregnancy, the parents must always be harmonious and peaceful (to each other), especially after seven months of pregnancy; they are not allowed to quarrel, and the husband should not be angry with his wife; (b) soon after birth adzan and iqomah rituals must be offered; (c) honey must be the first food given to the baby, and before the honey is given the feeder must pronounce basmalah ("In the name of Allah, the Beneficent, the Merciful") 786 times; (d) the mother must not suckle the baby while she is angry; (e) as soon as the child reaches three years of age he must be taught tauhid; (f) when he is five years old he must be taught to read the Qur'an and the knowledge of obligatory rituals; $(\mathrm{g})$ when he reaches adulthood he must be told to practice qana'ah, such as fasting or intensive practice of religious rituals, etc.; and $(h)$ the parents and the child should always prihatin (practice an austere life).

15. My personal records of the speech of Kyai Adlan 'Ali in the Pesantren Seblak.

16. Other santri, however, were told that the reason that all gus were accommodated in a special ward was so that other santri would not be influenced by those gus, who were mostly naughty.

17. The belief in kyai as the channel of God's sanctity and grace, however, is held only so long as the kyai are wira'i. 
founder and leader of the large pesantren of Gedang, East Java, in the third quarter of the nineteenth century; and finally Kyai Sihah, his great-grandfather, was the founder of Pesantren Tambakberas in Jombang.

Early in life he became noted for his intelligence, piety, and profound learning, all qualities considered fitting attributes to his noble birth. He studied first under his own father, concentrating on elementary theology, jurisprudence, exegesis of the Qur'an, hadith, and the other usual subjects for a Muslim student of the time. He was so brilliant that when he was only thirteen years old he could assist his father in teaching students who were much older than he. He continued his studies in various pesantren for two years, and later attended the famous pesantren of Siwalan, in Surabaya, for five years. Kyai Ya'kub, the leader of this pesantren, took him as a son-in-law and financed his further studies in Mecca. After only a year's stay in Mecca, his wife died, and so did his two-month-old child. He returned to Java with his father-in-law, but returned to Mecca again three months later.

This second stay lasted seven years, and during this time he was accompanied by his brother-in-law, Muhammad Alwi. Both continued their studies under learned syekh, such as Syekh Nawawi al-Banteni, Syekh Mahfudj al-Tarmisy and Syekh Ahmad Khatib. Upon their return, they together established the Pesantren Tebuireng in Jombang, which soon attracted many promising santri. Among these were Kyai Habib Termas, Anwar, Wahab Hasbullah, Bisri Syamsuri, As'ad, Manaf Abdulkarim, Abbas, Maksum, Adlan 'Ali, Baidlowi, Idris Kamali, Romli, and many others who later became important kyai in Java. It is necessary to mention these students, not only because of their subsequent prominence as kyai who led major pesantren, but also because Hasyim Asy'ari took most of them as relatives-in-law. Moreover, these students were also sons of important kyai throughout Java. (See the diagram pp. 56-57.) Hasyim Asy'ari's second father-in-law was the Kyai of Sewulan in Madiun, a descendant of Kyai Hasan Basari Tegalsari, a well-known kyai of the eighteenth century who had a close kin relationship with the kings of Kartasura.

\section{Extent and Cohesiveness of the Kindred and Affinal Relatives among the Javanese Kyai}

It is difficult to say whether the Javanese kyai have a concept of the kindred as a unit. Although they sometimes share the vague Javanese concept of kulawarga, sanak-sedulur, or just sedulur, which simply mean "relatives," the kyai's relatives form a tightly knit group. Firmly entrenched, with a distinctive kyai culture and sufficient landholdings, they maintain close relationships with a wide number of kinsmen. Most kyai are related through kinship and marriage, and they firmly maintain a tradition of holding pesantren leadership. They have also developed a tradition of keeping a record of their genealogies going back several generations, and, by means of strategically placed endogamous marriages, they constantly reinforce their strong kin organization.

More important than the concept of kulawarga is the Islamic concept of kinship, which divides all relatives into isih muhrim and dudu muhrim. ${ }^{18}$ The members

18. In Islam, it is obligatory for every Muslim to perform five daily prayers. Prayers begin with ritual purification. Certain kinds of contamination, such as that received from touching a pig or a dog must be washed seven times; that resulting from sexual intercourse must be removed by a complete bath. The prescribed purification for performing prayers is to free oneself of all bodily excretions and to wash the face from forehead to beneath the chin and from ear to ear, 
of isih muhrim are: one's parents and parents' siblings and upper generations, one's siblings and their descendants, and one's children and their descendants. They are thus one's nearest kin, close to the Javanese concept of sedulur cedak (near kin) as opposed to sedulur adoh (distant kin). The difference is that the category isih muhrim does not include nak-sanak (first cousins) as members, while sedulur cedak does. This is a very important difference, because the concept of isih muhrim denotes relatives who are barred from entering into matrimony with one another while the Javanese concept sedulur cedak does not. Moreover, the concept sedulur cedak is less definite, and its boundaries in practice are fluid. A close relative may become, in effect, distant as a result of a quarrel, geographic distance, or moving into another class. ${ }^{19}$

In contemporary Java, there has been a tendency among the kyai to develop an informal kinship organization called bani, which includes all members of sedulur cedak and sedulur adoh. The functions of the bani are not only to maintain close relationships with a wide number of kinsmen, but also to strengthen santri culture among its members, and to encourage endogamous marriage among dudu muhrim members. Here are my fieldnotes on a speech given by a leading figure of Bani 'Abduljabbar in its general meeting on May 20, 1978 in Surabaya:

It is our intention to set up a Lajnah Munakahah [Council for Marriage] which will be able to stabilize quarrels of our married couples and to encourage arranged marriage among our members. Our regular meetings are also intended to remind us from time to time that our members should always behave according to the way of life of our Mbah [Grandfather] 'Abduljabbar, a well-known kyai who was always faithful to God. It is a shame that, as a member of Bani 'Abduljabbar, a person is not able to read the Qur'an or does not perform his daily obligatory prayers. We remind you, do not deviate from the teachings of Mbah Abduljabbar.

The members of a bani are expected to regard the pesantren founded by their apical ancestor as their common property and on certain occasions to visit his tomb. They are also expected to call on the bani's oldest member as a symbol or an expression of their affiliation to the bani.

From the point of view of the individual, there is a pool of relatives which can be drawn on for assistance at various stages in one's life, the degree of distance being the measure of the strength of one's claim. Every member of a bani knows that he is genealogically closer to some members than he is to others, and he knows that this affects his social relations with them. He knows full well that closer kin feel more strongly obliged to assist with their resources, especially those who share the same parents or grandparents.

Like all other Javanese kindred, members are expected to help with such festivities as weddings, circumcisions, and births by substantial contributions of food, money, and labor. The kyai's kin groups, which are comparatively more cohesive than those of the average Javanese, can marshal a large quantity of goods and facilities from among themselves for these occasions, a fact which adds

the feet, and the arms up to the elbows, and to wet the hair. Several things can invalidate the state of ritual purity necessary for prayer, for example, falling asleep and touching the skin of dudu-muhrim of the opposite sex. Touching a member of the category isih muhrim, however, does not invalidate the state of ritual purity.

19. Hildred Geertz, Javanese Family, pp. 24-25. 


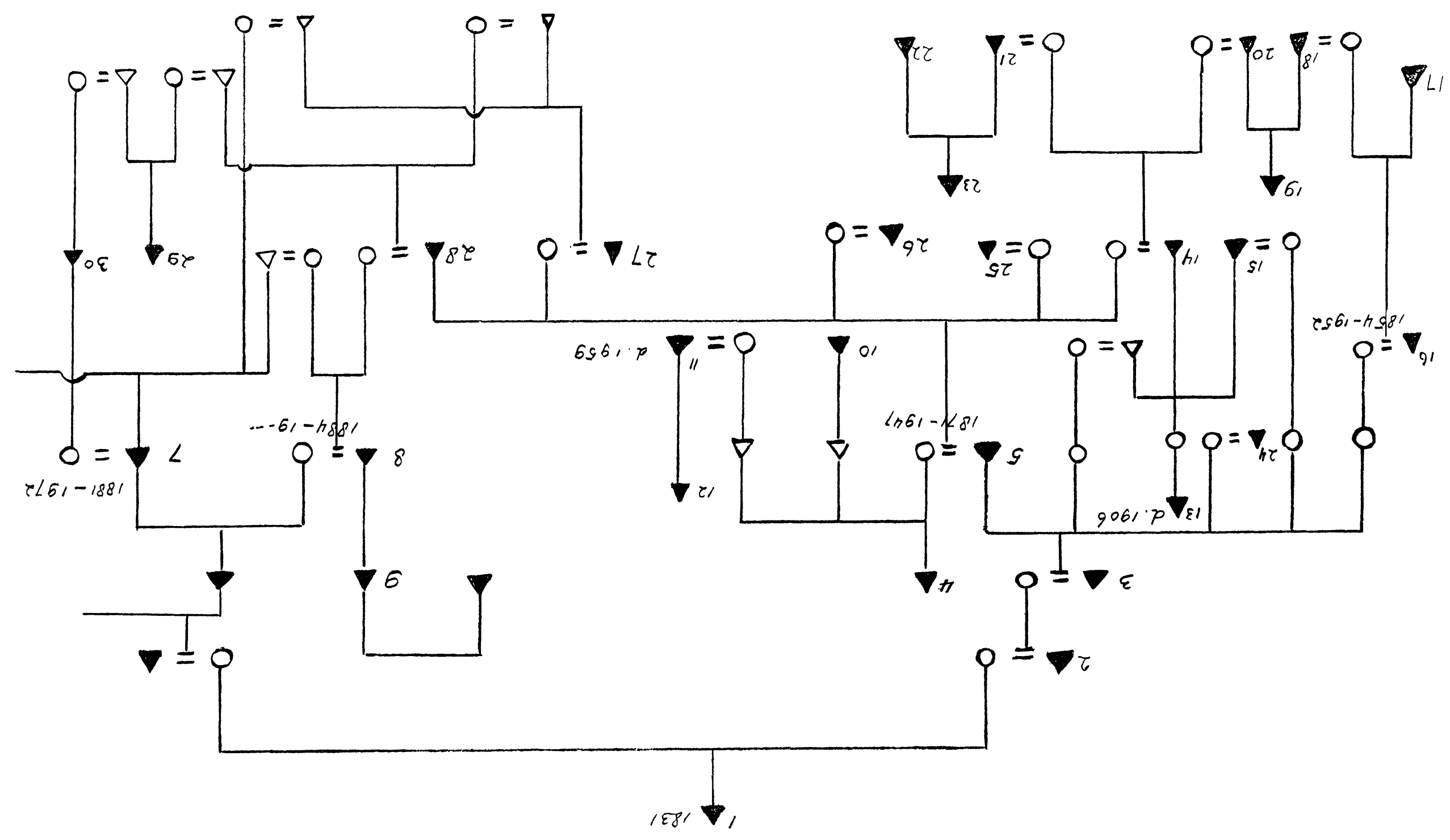




\section{PATTERNS OF KINSHIP AMONG THE KYAI}

1. Kyai Sihah, the founder of Pesantren Tambakberas

2. Kyai Usman, the founder of Pesantren Gedang

3. Kyai Asy'ari, the founder of Pesantren Keras

4. Kyai Ilyas of Pesantren Sewulan

5. Kyai Hasyim Asy'ari, the founder of Pesantren Tebuireng

6. Kyai Hasbullah, the successor of Pesantren Tambakberas

7. Kyai Wahab Hasbullah, (as above)

8. Kyai Bisri Syamsuri, the founder of Pesantren Denanyar.

9. Kyai Tayu, Rembang

10. Kyai Ilyas (Mohammad Ilyas), Minister of Religious Affairs

11. Kyai Romli, the successor of Pesantren Peterongan

12. Kyai Tamim, the founder of Pesantren Peterongan

13. Kyai Abduljabbar, the founder of Pesantren Maskumambang

14. Kyai Maksum, the founder of Pesantren Seblak

15. Kyai Adlan 'Ali, the founder of Pesantren Cukir

16. Kyai Manaf Abdulkarim, the founder of Pesantren Lirboyo

17. Kyai Mahrus, the successor of Pesantren Lirboyo

18. Kyai Mansur Anwar, the successor of Pesantren Paculgowang

19. Kyai Anwar, the founder of Pesantren Paculgowang

20. Kyai Mahfudl Anwar, the founder of Pesantren Sunan Ampel

21. Kyai Nurazis, the successor of Pesantren Seblak

22. Kyai Masykur, currently the Vice Chairman of Parliament

23. Kyai Maksum, the founder of Pesantren Singosari Malang

24. Kyai Alwi of Pesantren Keras

25. Kyai Idris of Cirebon

26. Kyai Habib Termas Dimyati

27. Kyai Ahmad Baidlowi of Banyumas

28. Kyai Wahid Hasyim, Penanda-tangan Jakarta Charter

29. Kyai Saifuddin Zuhri, former Minister of Religious Affairs

30. Kyai Ahmad Syaikhu, former Chairman of Parliament 
further to their actual wealth and prestige. Distant kin are expected to attend such affairs, but their contribution does not have to be more than that of a friend or neighbor. In everyday activities, members of the isih muhrim cooperate most closely and commonly render economic assistance to one another, but they do not act together as a group. The nak-sanak relationship is still considered important as the basis for mutual aid and assistance, but beyond the nak-sanak, ties become less important as the basis for mutual aid and assistance. The members of bani, however, encourage endogamous marriage between misanan (second cousin) and mindoan (third cousin). This preference is expressed in many ways, both in Javanese and in Arabic. A Javanese example is as follows:

The parents who are proposing to marry their son or daugher to a girl or boy who is still misanan or mindoan will usually approach the girl or boy's parents by saying: "Yu (my older sister) [or mas (my older brother), or some other appropriate classificatory kin term], I want to marry my child to yours. My own marriage has separated me (geographically) from our family. I want you to take my child as your mantu (your child-in-law) so that my children and grandchildren will not lose their ties with our family." This is what the Javanese call "ngumpulake balung pisah" which means that distant kin are recruited as close kin through marriage.

For a boy who is looking for a spouse, the kyai suggest that he follow the teaching of the Prophet as written in the Bulughul Maram: "Tunkahul mar'atu liarba'in, lidiniha, linasabiha, lijamaliha, wa limaliha," ${ }^{20}$ which means: "Marry a woman for the intensity of her religious devotion, her kin reputation, her beauty, and her wealth."

Marriage between misanan or mindoan is common among keluarga Kyai. Marriage between nak-sanak is not uncommon, but in general kyai try to avoid such marriages. Their attitude towards this is ambiguous; on the one hand, Islam allows such marriages which, therefore, have to be accepted as a right path. On the other hand, they feel that the nak-sanak relationship is so close that it is very hard to change it into an in-law relationship. My impression, however, is that if a nak-sanak requests marriage with his or her relative, more distant relatives, either misanan or mindoan, will not put forth a request until that of the nak-sanak has been dropped.

Marriage outside the circle of nak-sanak, misanan and mindoan is allowed, mostly to nuclear members of other kyai families. But it is almost impossible to marry co-villagers outside the nak-sanak, misanan, mindoan, or fringe members of other keluarga kyai. Beyond the range of mindoan (that means beyond the fourth generation), status as members of keluarga kyai fades gradually; the next generation is easily absorbed into the general Javanese society of nonkin. Only certain descent lines survive to be able to maintain exclusive endogamous marriage systems: almost invariably because one or two of their members succeed in becoming kyai and establishing their own pesantren. The rest are absorbed into the general society. Yet they maintain their santri culture, and regard their kyai descent line's culture as an important point of reference. I would suggest that the expansion of kinship ties among the Javanese kyai is one of the main contributors to the development and the expansion of santri culture and community in Java. This probably explains why the majority of the Javanese villagers who supported the $\mathrm{NU}$ Party in the last three general elections $(1955,1971$, and 1977) live in villages which are close to the pesantren.

20. Ibn Hajar al-'Asqalānī, Bulūgh al-marām (Yogyakarta: Penjiaran Islam, 1963), p. 149 . 